\title{
4.50 безопасности человеческой жизни в условиях глобализации
}

\section{Введение}

В современных социальных науках, идеологии и политике все большее значение приобретают концепции национального, глобального и человеческого развития. Это потому, что текущий процесс развития любого государства не проходит без этих трех столпов. По мнению известных сегодня политиков и экономистов, процессы холодной войны и «гонки вооружений» развиваются в новом направлении, называемом «энергетической войной», и порождают новые конфликты и напряженность. Глобализация - это процесс создания новой глобальной политической, экономической, культурной и информационной целостности. Этот термин впервые был представлен научному сообществу в 1983 году американским экономистом Теодором Левиттом.

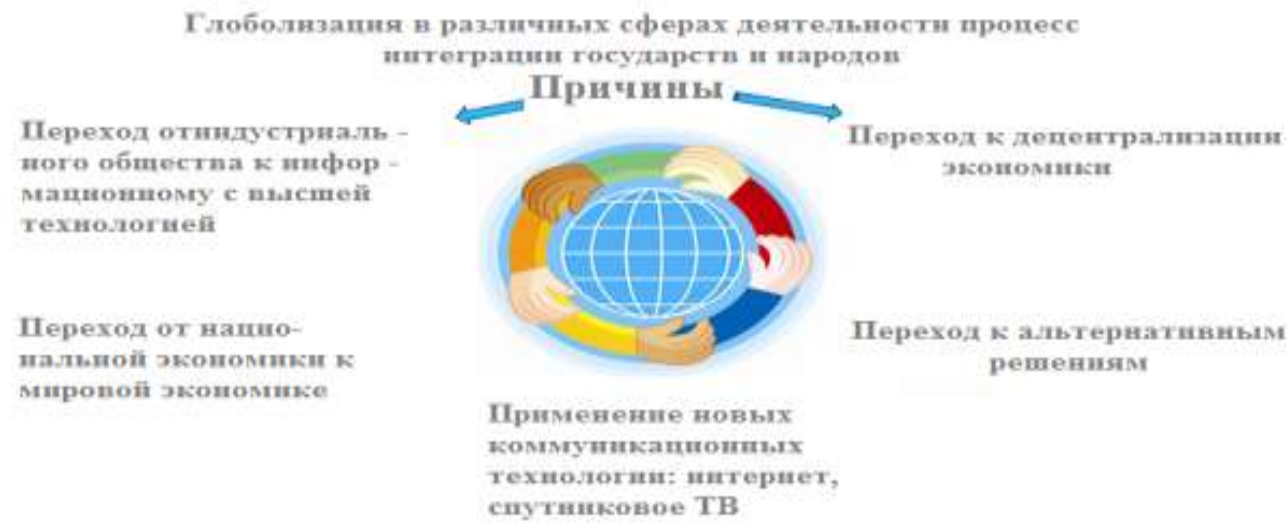

Рис.1. Основные причины глобализации

\subsubsection{0сновная часть.}

Обострение и глобализация экологических проблем со второй половины двадцатого века, прежде всего загрязнение и разрушение элементов окружающей среды, нехватка ресурсов, которые угрожают самой основе жизни и средств к существованию, и тем более для будущих поколений.

Возникновение такой ситуации было результатом практически неконтролируемого экономического роста, который требовал большего 
количества природных ресурсов, поскольку вся экономическая деятельность основана на использовании элементов окружающей среды (металлов, полезных ископаемых, почвы, лесов, рыбных ресурсов, энергии).

Глобализация мировой экономики способствовала у ухудшению окружающей среды из-за ускорения экономического роста. Хотя глобальный экономический рост ускорился, особенно за счет развивающихся стран, а финансово-экономический кризис вызвал рецессию во многих странах, в ближайшем будущем не может быть радикальных изменений в долгосрочной тенденции быстрого глобального экономического развития. .

Однако до 1960-1970 гг. Негативное влияние экономической деятельности наблюдалось только в отношении определенных компонентов окружающей среды, а затем распространялось на все ее компоненты. В последние десятилетия XX века и в начале XXI века это влияние особенно остро и носит глобальный характер, как с точки зрения его влияния на развитие мировой экономики, так и комплекса принимаемых для этого мер.

С середины двадцатого века мировая экономика и высокие темпы роста населения нанесли большой ущерб окружающей среде. В начале XXI века мировое промышленное производство увеличилось в 7 раз, население Земли увеличилось в 2,5 раза по сравнению с 1950 годом и сейчас составляет 7 миллиардов человек [316].

\subsubsection{1 Рост численности населения земного шара.}

К 2050 году население может вырасти еще на 2-2,5 миллиарда, к 2030 году растущему населению потребуется увеличить продукты питания и энергию на 50\%, пресную воду на 30\%, а к 2050 году производство продуктов питания должно вырасти на 70\%.

В начале 1990-х годов население Земли, по мнению некоторых ученых, сбросило максимально допустимую нагрузку на окружающую среду. Сегодня масштабы глобального производства и потребления привели к катастрофическому нарушению баланса природных и социальных систем и, по мнению многих ученых в различных областях науки, достигли своего предела, 
даже превышая способность окружающей среды справляться с Деятельность человека. Исследования показывают, что эти возможности превысили 25-30\%, а экологический долг человечества оценивается в 4 триллиона долларов.

Учитывая, что большинство экологических проблем возникает намного позже, чем их причины, даже если все необходимые меры будут приняты немедленно, качество окружающей среды будет ухудшаться в течение многих лет, в первую очередь из-за острых и долгосрочных проблем - изменения климата и истощения озонового

В настоящее время источниками экологически опасной деятельности являются в первую очередь транснациональные корпорации, поскольку они образуют основные производственные, инвестиционные и торговые связи в мире. В условиях глобализации обострение экологических проблем связано с ограниченными возможностями национальных правительств и международных организаций контролировать и регулировать деятельность транснациональных корпораций, что приводит к расширению их полномочий и бесконечному росту торговли и инвестиций [317].

В понятие глобальной экологической проблемы входят различные глобальные экологические проблемы, основными из которых являются нехватка ресурсов, разрушение компонентов и загрязнение окружающей среды, а также влияние социальной среды. Разделение на отдельные комплексы этих проблем условно, так как все они тесно связаны между собой, а одни приводят к возникновению других. Одна из важнейших проблем - нехватка ресурсов, что связано с чрезмерным и зачастую нерациональным характером их потребления, прежде всего в развитых странах.

\subsubsection{2 Истощение природных ресурсов.}

Уровень использования возобновляемых ресурсов, в частности пресной воды, лесов, верхнего слоя почвы и морских рыбных запасов, превышает скорость естественного восстановления на глобальном уровне. За последние 50 лет человечество использовало больше ресурсов, чем когда-либо прежде. Только в 1970-1995 годах мировое потребление сырья (за исключением продуктов 
питания и топлива) увеличилось вдвое. По данным Программы Организации Объединенных Наций по окружающей среде (ЮНЕП), нехватка пресной воды является важной экологической проблемой из-за ее высокого уровня загрязнения и нерационального использования в контекст устойчивого роста населения.

Недостаток воды отрицательно сказывается на сельском хозяйстве, особенно на искусственно орошаемых сельскохозяйственных угодьях, поскольку около 65\% воды расходуется на производство сельскохозяйственной продукции. Расход воды на единицу продукции в крупных агрокомплексах намного выше, чем в малых хозяйствах. Некоторые виды современных высокотехнологичных производств, такие как компьютерные чипы, также требуют большого количества чистой воды[318].

Вымирание компонентов окружающей среды также является глобальной экологической проблемой: вырубка лесов, особенно в тропиках - основных продуцентах кислорода в атмосфере Земли, наступление пустынь и засоление плодородных земель, коралловые рифы, угрожающие неодушевленному пространству океана. В настоящее время сохранилось только $35 \%$ девственных лесов мира, в то время как в США потеряно 85\% таких лесов, а в Европе их практически нет.

\subsection{2. Парниковый эффект}

В результате деятельности человека исчезла половина тропических лесов мира. Это 1990-2005 годы. Площадь лесов уменьшилась в среднем на 0,2\%. Их обезлесение способствует расширению зоны пустынь и влияет на глобальный климат из-за увеличения содержания углекислого газа в атмосфере. По оценкам, сокращение площади лесов равно дополнительным 20-25\% выбросов парниковых газов в атмосферу. Кроме того, обезлесение приводит к эрозии почвы и истощению пахотных земель, которые являются источником пищи, нарушением водных систем и экосистем. Существование 350 миллионов человек в мире напрямую связано с существованием лесов.

Наибольшую угрозу для жизни и здоровья человека представляет быстрое загрязнение окружающей среды в результате антропогенных процессов 
долгосрочными разлагающимися соединениями. Химическое загрязнение, которое приводит к глобальному потеплению и истощению озонового слоя Земли, имеет самые серьезные последствия [319].

Проблема глобального потепления, представляющая угрозу для человечества, признана наиболее важной и всеобъемлющей. Многие ученые связывают изменение климата с увеличением выбросов в атмосферу, в основном называемых парниковыми газами: диоксид углерода, метан, оксиды азота и некоторые виды углеводородов хлорофтора.

В 2005 году концентрация парниковых газов в атмосфере была на 35\% выше, чем полтора века назад. По мнению ученых, увеличение концентрации связано с антропогенными источниками, включая производство, переработку, использование материалов, сельское хозяйство и удаление отходов. При этом основной причиной является производство топлива и энергии, в результате чего около 65\% всех выбросов парниковых газов в мире производится за счет антропогенных источников. После промышленной революции 2007 года выбросы углекислого газа при сжигании топлива увеличились с нуля до 29 ГВт.

\subsubsection{1 Страны загрязнители атмосферы}

Основными загрязнителями являются не только развитые страны, но и такие быстрорастущие страны, как Китай и Индия. В 2007 году Китай впервые занял первое место в мире по выбросам углерода от сжигания топлива: его доля составила 20,9\%. На втором месте оказались США с долей 19,9\%. Другими основными загрязнителями были ЕС - 11,3\%, Россия - 5,4\% и Индия - менее 5\%. Глобальное потепление уже имеет серьезные негативные последствия и затрагивает многие страны, нанося ущерб их экономике. В будущем изменение климата может иметь еще более серьезные последствия, включая выживание человека.

Потепление приведет к таянию ледников и поднятию уровня Мирового океана, изменению морских течений, распространению опасных насекомых и неизвестных инфекций среди людей. Климатические дисбалансы приводят к увеличению количества и масштабов стихийных бедствий: ураганов (включая 
ураган Катрина в 2005 году), тайфунов, цунами (например, сильное цунами в Индийском океане в 2004 году), засух (например, беспрецедентной засухи в Центральная Россия в 2010 г.).) наводнения, наблюдавшиеся в последние годы в Европе, Японии, США, России, Азии и других регионах. Количество стихийных бедствий (исключая геологические причины, такие как землетрясения и извержения вулканов) увеличилось с 233 в 1950-х годах до 3800 в первом десятилетии 21 века, а число пострадавших увеличилось с 20 миллионов до 2 миллиардов [320].

Изменение климата подрывает глобальную продовольственную безопасность, влияя на продуктивность сельского хозяйства, экосистемы и утрату биоразнообразия. Последние данные показывают, что глобальное потепление может привести к сокращению посевных площадей под пшеницей в Южной Азии на 50\%. По оценкам, 17\% пахотных земель в Китае и 28\% в Индии подвержены эрозии и другим формам деградации земель. Потепление также приводит к гибели коралловых рифов, которые являются источником жизни в морях и океанах.

\subsubsection{2 Изменение мирового климата}

Изменение климата обостряет другие глобальные проблемы: уменьшает количество ресурсов (в том числе пресноводных, рыбных ресурсов), приводит к дальнейшему истощению компонентов природной среды - вырубке лесов, опустыниванию, засолению почв и другим. Сложность решения проблемы глобального потепления зависит от его долговременности.

Учитывая взаимоотношения в природе, негативные последствия изменений окружающей среды наблюдаются уже много лет. Он направлен на объединение усилий мирового сообщества на местном, региональном, национальном и международном уровнях для оценки изменений ситуации и принятия эффективных мер по решению этой важнейшей глобальной проблемы.

Проблема отходов, особенно опасных (прежде всего ядерных отходов и их захоронения), представляет большую угрозу для окружающей среды. Оценки отходов, производимых разными организациями, значительно различаются из-за 
сложности их подсчета. По одной из оценок, ежегодно в мире образуется до 100 миллиардов тонн твердых отходов, в том числе при добыче полезных ископаемых, электроэнергии, автомобилей и т. Д. появляется.

Другими крупными производителями этого типа отходов являются Китай, Япония, Бразилия, Индия и Франция. По оценкам экспертов Базельской конвенции, в 2000 году было выброшено более 300 миллионов тонн опасных отходов. Около 90\% всех выбросов были классифицированы как опасные, а 30\% - как стойкие органические загрязнители. Более 90\% отходов поступает из развитых стран. Ситуация особенно тяжелая в развивающихся странах, где собирается 30-60\% всех твердых бытовых отходов.

\subsubsection{3 Опасные отходы}

В настоящее время количество опасных отходов связано с их новыми видами - компьютерами, мобильными телефонами и т. Д. б. очень быстро растет из-за появления. К значительным глобальным экологическим проблемам относятся, прежде всего, социальные аспекты развития стран, связанные с их высокими темпами прироста населения.

Прогнозируется, что к 2050 году 85\% населения мира будет проживать в развивающихся странах, где питание, жилье, работа, образование и здравоохранение особенно затруднены. Высокие темпы роста населения в развивающихся странах обычно требуют ускоренного экономического роста, что, в свою очередь, приводит к ухудшению состояния окружающей среды.

Невозможно эффективно решать экологические проблемы без решения проблем развития, в том числе проблемы увеличения неравномерности распределения прибыли от быстрого глобального экономического роста из-за глобализации. Значительные различия в уровне благосостояния развитых и развивающихся стран препятствуют решению проблем развития. Несмотря на то, что средний доход на душу населения в мире сейчас превышает 5 тысяч долларов, 2,8 миллиарда человек в год (2 из 5) живут менее чем на 2 доллара в день. 
Около $1 \%$ самых богатых людей на Земле зарабатывают доход, сопоставимый с доходом 57\% бедных. Хотя число бедных с 1990 года уменьшилось на 0,4 миллиона, все это сокращение произошло за счет Китая, в то время как абсолютное число бедных увеличилось в странах Африки к югу от Сахары и Южной Азии. Развитые страны вкладывают значительные средства в окружающую среду, а в развивающихся странах такие возможности ограничены. Поэтому решение проблем развития - одна из важнейших задач, стоящих перед человечеством, которая является экологической потребностью и требует совместных усилий мирового сообщества [320].

\section{Выводы}

Возникновение и дальнейшее обострение глобальных экологических проблем связано с неопределенностью и неравномерностью глобализации мировой экономики, оказывающей существенное влияние на окружающую среду. В контексте глобального экономического роста, во многом благодаря ТНК, преобразование окружающей среды потребовало принятия мер, которые приведут к радикальным изменениям в регенеративной системе планеты, и начали влиять на все страны и всех людей на Земле.

Расширение мировой экономики приведет к увеличению использования природных ресурсов за счет увеличения экспорта нефти, лесов и других природных ресурсов, что приведет к увеличению загрязнения окружающей среды и обострению других глобальных проблем.

Многолетние исследования показали двойное воздействие международной торговли на окружающую среду, многие из которых имеют негативные последствия. Примерами негативного воздействия на окружающую среду расширения производства являются кожевенная, красильная и текстильная промышленность Китая и Пакистана: рост экспорта их продукции привел к резкому увеличению производства, что привело к значительному увеличению производства. экологическое давление и экологический ущерб. 